\title{
Consumption smoothing and price enhancement motives for grain storage: empirical perspectives from rural Ethiopia
}

\author{
Wondimagegn Tesfaye ${ }^{1}$ and Gebrelibanos Gebremariam ${ }^{2,3^{*}}$ (D)
}

\author{
* Correspondence: g.gebremedhin@ \\ gmail.com \\ ${ }^{2}$ Mekelle University, 231 Mekelle, \\ Ethiopia \\ ${ }^{3}$ Center for Development Research \\ (ZEF), University of Bonn, \\ Genscherallee 3, 53113 Bonn, \\ Germany \\ Full list of author information is \\ available at the end of the article
}

\begin{abstract}
Consumption smoothing and temporal price arbitrage are the two main economic motives for grain storage in semi-subsistence economies. Nonetheless, little has been documented on the determinants of households' grain storage behavior. Using a rich panel data from maize producing households in Ethiopia, this paper investigates the determinants of households' decision to store grain for consumption and/or for the market. We found that grain storage is mainly determined by climatic factors, technological innovations, and shocks. Grain storage for consumption and for the markets are not mutually exclusive decisions. While the decisions made by the households to store maize for consumption and for the markets are influenced by a host of similar factors, the effects of climatic factors and infrastructure are found to be heterogeneous.
\end{abstract}

Keywords: Grain storage, Precautionary savings, Consumption smoothing, Temporal arbitrage, Shocks, Ethiopia

JEL codes: D13, O12, Q12, Q18

\section{Introduction}

The economic role of crop storage in the face of exogenous shocks can best be explained by the often-quoted biblical account of Joseph's interpretation of Pharaoh's dream. Joseph foretold Pharaoh that seven years of the abundant harvest would be followed by seven years of famine and recommended that the king stores grain during the good years as a hedge against the famine years. Since then, there has been a growing interest in understanding the role of grain storage and the factors governing actors' storage decisions. This is imperative particularly in developing countries where agricultural production is seasonal, and this seasonality is accompanied by notoriously low and uncertain income that translates to consumption shortfalls in the lean season (Basu and Wong 2015; Paxson 1992; Saha 1994). Rural households in developing countries face a plethora of weather-related income shocks, which have significant economic effects (Dercon 2004; Kazianga and Udry 2006; Beegle et al. 2006; Baez et al. 2015). Savings and credit are among the attractive responses to income and

(c) The Author(s). 2020 Open Access This article is licensed under a Creative Commons Attribution 4.0 International License, which permits use, sharing, adaptation, distribution and reproduction in any medium or format, as long as you give appropriate credit to the original author(s) and the source, provide a link to the Creative Commons licence, and indicate if changes were made. The images or other third party material in this article are included in the article's Creative Commons licence, unless indicated otherwise in a credit line to the material. If material is not included in the article's Creative Commons licence and your intended use is not permitted by statutory regulation or exceeds the permitted use, you will need to obtain permission directly from the copyright holder. To view a copy of this licence, visit http://creativecommons.org/licenses/by/4.0/. 
consumption shocks, as they transfer assets from one season to another (Basu and Wong 2015; Paxson 1992). However, imperfections in the savings and credit markets (Stephens and Barrett 2011) create difficulty in smoothing consumption (Basu and Wong 2015).

In the absence of or amidst poorly functioning credit and insurance markets (Rosenzweig and Wolpin 1993; Udry 1990), rural households in developing countries shield themselves against shocks through numerous informal risk-sharing arrangements or self-insuring mechanisms (Udry 1995) ${ }^{1}$. Informal risk-sharing mechanisms are less effective in either maintaining or improving welfare particularly in times of covariate shocks that uniformly affect households (Dercon 2002; Dercon and Christiaensen 2011; Park 2006). It is also common to observe rural households engage in costly risk coping strategies such as the depletion (selling) of productive assets (Janzen and Carter 2013) that have negative repercussion on household well-being and adaptive capacity both in the short and long run (Carter et al. 2007; Carter and Lybbert 2012; Dercon and Christiaensen 2011; Dercon 2004; Hoddinott 2006; Kazianga and Udry 2006). In the absence of formal risk coping options, households hold their assets in the form of grain stocks (Ali 2015; Park 2006; Saha and Stroud 1994; Saha 1994; Udry 1995), livestock (Ali 2015; Kazianga and Udry 2006; Rosenzweig and Wolpin 1993), and other productive assets (Park 2006; and Ali 2015) as risk coping mechanism. Asset holdings in the form of livestock and farm implements, for instance, might be less effective for consumption smoothing or risk coping (Fafchamps, Udry, and Czukas 1998; Kazianga and Udry 2006). The use of grain buffer stocks as a form of savings for income smoothing after a shock has proven to be a very important coping mechanisms (e.g., Udry 1995; Fafchamps et al. 1998), and could act as an insurance for consumption smoothing against harvest failure and market shocks (Park 2006; Ali 2015). The accumulation of crops or liquid assets as a buffer against shocks serves as a mechanism for consumption smoothing or precautionary savings (Lim and Townsend 1998). In an environment of incomplete rural capital markets, and coupled with the seasonal nature of agricultural production, on-farm storage could serve as a primary means of consumption smoothing and a means for asset or income transfer (Ali 2015; Saha 1994; Saha and Stroud 1994). Grain storage could also serve as a commitment device for savings by discouraging frequent withdrawals (Ashraf et al. 2006). In the absence of national storage systems or national reserve stocks, maintaining grain stocks at the household level serves as an insurance against consumption risks, which could lead to an instantaneous increase in food prices particularly in areas where markets are less integrated. (Paxson 1992; Park 2006).

Despite the substantial economic role of grain storage, there is scanty yet nascent theoretical and empirical literature on households' grain storage behavior and motives for grain storage. Renkow (1990) is the first in the agricultural household literature to model on-farm storage decisions of semi-subsistence households under risk. He pointed out two factors that may motivate semi-subsistence households to hold inventories of staple foods. First, households might want to minimize their reliance on local (food) markets and hold stocks of food as a contingency against unanticipated supply

${ }^{1}$ See Fafchamps and Gubert (2007); Fafchamps and Lund (2003); Ng'ang'a et al. (2016); Udry (1994); Rosenzweig and Wolpin (1993); Kazianga and Udry (2006); Beegle et al. (2006); Jalan and Ravallion (2001); Skoufias (2003) for the common shock coping strategies. 
disruptions. In line with this, households may also have the desire to diversify their portfolio of asset savings to minimize risk ${ }^{2}$. Another motive for holding inventories of home-produced staples might be the profit-seeking or speculative desire of households in response to seasonal price movements. Farmers tend to store grains after harvest for the purpose of arbitrage when they anticipate price increments. In a related study, Saha and Stroud (1994) argue that price arbitrage is a partial and relatively unimportant reason for farmers' on-farm grain storage decisions in less developed countries. They rather contend that on-farm grain storage is a de facto form of forward contract to meet the farm household's consumption needs under price risk. Thus, it is rational for farmers to store grain for food security or consumption reasons. Supporting this, a complete storage model by Park (2006) shows that food security or supply risk coping is a key push factor for grain storage in the subsistence farming system of developing countries, even when there is no possibility of gain through price arbitrage (Renkow 1990; Saha and Stroud 1994). Saha (1994) presents a two-season model of household's production, consumption, labor supply, and storage decisions in an environment of output and price risk.

In general, there is no agreement in the literature on the motives for grain storage in Sub-Saharan Africa. For example, Tadesse and Guttormsen (2011) emphasize that farmers are among the major economic agents who hold grain stock for speculation purposes. In contrast, Ali (2015) argues that the subsistence nature of the agriculture sector in many of the developing countries (e.g., Ethiopia) compels households to hold grain stocks mainly to ensure future food supplies rather than for sales in anticipation of future increases in grain prices. Thus, the nature of the relationship between farm households' on-farm storage decision for future consumption and markets (to sell later at higher prices) remains an empirical question. Moreover, little attention has been given to the determinants of grain storage behavior with a focus on the heterogeneity of effects on grain storage for consumption and markets. We argue that this paucity in the literature needs to be addressed.

Within the purview of storage economics, another issue of interest is why some households store more while others store less or none of their harvest. While grain storage is a common practice among households in many of the developing countries, it is evident that many farmers store little of their harvest (if they do), usually for a short period of time, and still sell at low prices in the postharvest season (Gabriel and Hundie 2006; Stephens and Barrett 2011; Tadesse and Guttormsen 2011). The key factors identified in the literature that would affect household's grain storage decisions include risk perception of storage loss (Fuglie 1995), liquidity constraints (Basu and Wong 2015; Stephens and Barrett 2011; Sun et al. 2013; Tadesse and Guttormsen 2011), and poor market access and market imperfections (Basu and Wong 2015; Saha and Stroud 1994). The anticipation of high storage losses due to poor access to improved storage technologies would raise the inter-temporal storage costs to the point that storing crop output for future sales becomes unprofitable (Fuglie 1995). Stephens

${ }^{2}$ See Ali (2015) for discussion of how livestock serves as a hedge against income shocks. We adjusted for the effect of livestock holding (and income from livestock sale) on crop savings in our empirical model. The focus of this paper is mainly on the effect of cash crop production, savings, and income from cash crop on grain savings for consumption and market. Households engage in cash crop production that generates a diversified farm portfolio to mitigate income risk. 
and Barrett (2011) find that there is a low demand for crop storage among western Kenyan households. They also demonstrate that households have a "sell low - buy high" behavior that is attributed partly to liquidity constraints and transaction costs. Sun et al. (2013) also find that Chinese maize farmers (mainly poor) with debt sell their maize much earlier than debt-free households, thus potentially losing inter-temporal arbitrage opportunities. Tadesse and Guttormsen (2011) also note that high storage costs and liquidity constraints force rural households in Ethiopia to sell the bulk of their produce immediately after harvest. A concern for price risk is another possible reason for the low demand for storage in developing countries where erratic seasonal price movements are ubiquitous (Basu and Wong 2015; Saha and Stroud 1994) ${ }^{3}$. Staple grain prices in Sub-Saharan Africa, for instance, fall precipitously in the postharvest period and reach their lows, and then sharply rise throughout the rest of the year as market supply dwindles, before they fall again at the harvest time. Price seasonality, coupled with poor storage technologies and liquidity constraints, would make storage costly and difficult, which in turn raises the opportunity cost of inter-seasonal transfer of grain (Kurosaki and Fafchamps 2002; Basu and Wong 2015).

The current body of evidence on the economics of grain storage behavior by rural households is scanty. While most of the theoretical models on commodity storage are developed in a developing country's context, there are only a few empirical studies that investigate household grain storage decisions in Sub-Saharan Africa. This paucity in the literature calls for an investigation into the factors governing households' grain storage behavior, mainly the interrelationship between grain storage for consumption smoothing versus grain storage for sale in the markets at a later period (temporal price arbitrage). This serves as the focus of the current research. For this purpose, we use a nationally representative panel data from maize farmers in Ethiopia. Maize is selected since it is both a staple food and a tradable grain in sub-Saharan Africa, especially, in southern and eastern Africa.

The paper contributes to the economic literature by bridging information gaps on precautionary savings, grain storage, and risk management in three ways. First, we develop a theoretical model of household grain storage that captures households' grain storage motives for food security and temporal price arbitrage in a single framework. Second, the paper employs a fixed effects model to identify the effect of shocks, climatic factors, and the geographic environment on maize storage. One novelty in this paper is the inclusion of many indicators of shocks and climatic factors that serve as a proxy for supply-side determinants of grain storage decisions. Besides, we include improved storage technologies and crop protection practices which are theoretically expected to positively affect grain storage level through mitigating the risk of grain storage loss. Third, the paper empirically investigates the effect of climatic factors, liquidity constraints, shocks, improved storage practices, and household heterogeneity on the two economic motives for grain storage: food security and price arbitrage. The paper has pivotal policy contributions. The degree to which households hold grain stocks plays a crucial role in the future prospects for economic growth in rural communities. Hence, understanding the determinants of grain storage provides evidence for the design of effective

${ }^{3}$ Against this argument, other studies (e.g., Saha and Stroud 1994; Barrett and Dorosh 1996; Park 2006) show that households hold grain stocks as a price risk hedge ex ante and that price risk aversion would induce grain stock holding postharvest, contrary to the sell low—buy high puzzle. 
policies aimed at increasing growth opportunities for rural households in Sub-Saharan Africa.

The rest of the paper is structured as follows. The "Conceptual framework" section presents the conceptual framework that guides the choice of the empirical strategies. The "Methods" section discusses the empirical models and describes the data used for the paper. The "Data, variables, and descriptive statistics" section presents and discusses the econometric model results. Conclusions are drawn and policy recommendations are made in the last section.

\section{Conceptual framework}

The theoretical framework for this paper is based on the agricultural household model (Singh, Squire, and Strauss 1986; Taylor and Adelman 2003) and commodity storage models (Basu and Wong 2015; Park 2006; Renkow 1990; Saha 1994; Saha and Stroud 1994). The paper integrates two distinct but contemporaneous streams of the theoretical literature: utility maximization models to analyze households' optimal choice of consumption and storage and household's risk responses both in the short and long run in an environment of incomplete rural capital and insurance markets (Saha 1994). A household commodity storage model of Park (2006) and Saha (1994) accentuates that storage decision is made in a coordinated manner with production and consumption decisions. Storage bridges production and consumption and balances the goals of utility maximization and reducing price risk (Park 2006).

We assume that there are two seasons (harvest and lean) where the household allocates its harvest between home consumption and sale in the markets. In the two seasons, the utility derived by the household is a function of the consumption of grain staple and the consumption of other purchased goods. During the harvest period, a farming household is assumed to have realized a positive endowment of maize grain harvest that would be allocated to consumption in both the harvest and the lean season. Furthermore, grain storage serves as a savings instrument that enables farmers to store part of the grain harvested in the main season for consumption in the lean season. Produce/harvest allocation decisions are made by the households during the main season, ensuring that some quantity of the harvest is stored for consumption in the lean season. Therefore, the quantity of crop harvested in each season will be consumed during the harvest season, sold to a marketer, and/or stored either for future consumption or sale to the markets. Consumption of harvest includes consumption as food, repayment for in-kind inputs (including labor, land, or other cash requirements), processing of harvest for animal feed, etc. ${ }^{4}$

Theoretically, the utility is derived from the consumption of on-farm produced grain and purchased goods. On the other hand, grain storage reduces the harvest period consumption by diverting part of the grain (resources) to the lean season period consumption (Basu and Wong 2015). However, grain storage is theorized to be a positive determinant of the utility in the lean season period through consumption smoothing or supply risk coping (when the grain is stored for future consumption) and/or price arbitrage (when the grain is stored for sale to the markets in the postharvest season). Hence, the household faces the problem of optimal storage that would maximize utility

${ }^{4}$ See Basu and Wong (2015) for details of households' inter-temporal crop disposition pattern. 
both in the harvest and lean seasons. Therefore, the household's storage behavior will be determined by the quantity of maize harvested, costs of consumption smoothing, and storage costs.

Storage is a productive activity that transfers a commodity from one season (e.g., harvest season) to the next (e.g., lean season) (Basu and Wong 2015). However, the amount of harvested maize product that is stored can still deteriorate over time. Storage also involves other opportunity costs of handling harvest over periods of time. Earlier studies assume that grains have reasonably constant marginal physical storage costs (Wright 2011) and the deterioration and interest rate to be constant over time (Wright and Williams 1982). However, shrinkage would vary with time, improved storage use, market access, and other factors (Saha 1994).

The standard utility maximization theory holds that households' consumption of marketed goods will be limited by their budget constraints. The main source of income for the household is agriculture (on-farm) production and off or nonfarm incomegenerating activities. The income generated by the household in each period is the sum of income from grain sales, the returns on any savings from the previous period, and any other exogenous income ${ }^{5}$. Income is spent on purchases of the marketed good, grain, and other household expenditures. Grain can flow into the household from ownfarm production and purchases. Grain dispositions are composed of consumption, storage in the current period, and sales.

Given the nature of market failures in rural Ethiopia, households are assumed to be credit constrained. In each period, the household is assumed to have a certain level of grain and financial wealth. We assume that there is no grain carryover from the previous period. This is a plausible assumption since most farmers in developing countries are net buyers during the lean season; hence, crop in storage is not carried over beyond one crop cycle (Saha 1994). Additional factors that could substantiate this assumption are the lower crop prices during the harvest season of the next period and the absence of improved storage technologies. Storage loss for most food crops is an increasing and convex function of the duration of storage (Saha 1994). Thus, the farm household has no incentive to carry their crop inventory over one crop cycle.

One plausible reason for on-farm storage is the possibility of inter-temporal price arbitrage that depends on strictly positive optimal storage. For a market-oriented producer, the decision to store crops particularly for markets would be determined by price expectations. A positive storage level will be observed only if the expected discounted future price exceeds the sum of the spot price plus storage cost. When storage is positive, the expected next period price is proportional to the current price and the expected return to grain storage equals the interest rate. These conditions define market equilibrium in the face of stochastic shocks. The household faces the problem of determining the discounted optimum level of storage that would maximize the utility subject to a budget constraint, storage costs, and risk

\footnotetext{
${ }^{5}$ Transaction costs mainly result from a lack of public physical and institutional infrastructure and are a barrier to accessing the market. For the sake of simplicity, we assume households face same transaction costs for marketing staples (grain) and cash crops. This is not a restrictive assumption given that transaction costs often do not vary over time.
} 
aversion. The household (farmer) strives to maximize its utility subject to these various constraints.

\section{Methods}

The interest of this paper is to analyze the determinants of grain storage behavior at the household level. Grain storage decision is potentially endogenous as it is a voluntary decision and may be correlated with unobservable characteristics. This urges controlling for any time-invariant component (e.g., preferences, fixed costs, innate ability). Empirical estimation in the presence of statistical endogeneity would lead to biased coefficients which thus would not be identified. Since conventional methods (e.g., ordinary least square method) are not capable of dealing with endogeneity, this paper employs a panel data econometric model (e.g., Bezu et al. 2014; Smale et al. 2015).

\section{Determinants of grain storage}

Households' storage decision (amount of maize stored during harvest) is estimated as a function of climatic factors, shocks, technologies, wealth, and other household characteristics. The relationship between the amount of maize stored and the explanatory variables is represented using a general linear unobserved effects panel data model:

$$
s_{i t}=\beta_{i} x_{i t}+\alpha_{i}+\theta_{t}+v_{i t}
$$

Where $i=1, \ldots, N$ indexes the household in the panel and $t=1, \ldots, T$ indexes time. $x_{i t}$ is a vector of other explanatory variables including climatic factors, storage innovations, economic environment, wealth, liquidity constraints, and other household characteristics. $\alpha$ and $\theta$ are individual and time fixed effects and $v_{i t}$ is the composite error term. The parameters of interest estimated are $\beta_{i}$. There are various ways of estimating the above equation. We employ fixed effects model to identify the true effects of the key explanatory variables after controlling for unobserved individual heterogeneity (Nguyen 2012). A household fixed effects control for the effect of householdspecific preferences for producing and consuming maize, production skill, innate ability, location-specific endowments such as agro-ecology, and household-specific transaction costs on storage decision and storage for food security or markets (Bellemare et al. 2013; de Janvry et al. 1991). Time-invariant household fixed effects provide further control for macroeconomic factors such as inflation, interest rates, and the international price of commodities. The use of fixed effects also ensures that estimates are unbiased and consistent (McCaffre et al. 2012).

The other objective of this paper is to model the determinants of households' storage motives: consumption or market. We utilize a bivariate probit model that enables modeling the two decisions simultaneously and explore their potential relationship (Plum 2016). The model also allows for interactions between unobserved factors associated with the two outcomes. Instead of modeling the determinants of grain storage for consumption and storage for the market in separate equations, we chose to jointly model the determinants in a two-equation system. This allows the regressors to have potentially different effects on each outcome, and also the 
unobserved characteristics that affect both outcomes to be correlated. The relationship between the two variables is represented as follows:

$$
\begin{aligned}
& S_{1 i}^{*}=x_{1 i}^{\prime} \beta_{1}+\epsilon_{1 i} \\
& S_{2 i}^{*}=x_{2 i}^{\prime} \beta_{2}+\epsilon_{2 i}
\end{aligned}
$$

with $S_{1 i}=1\left(S_{1 i}^{*}>0\right)$ and $S_{2 i}=1\left(S_{2 i}^{*}>0\right)$

where $S_{1 i}^{*}$ and $S_{2 i}^{*}$ represents grain stored for consumption and for market, respectively. $x_{1, i t}$ and $x_{2, i t}$ are a matrix of explanatory variables included in the model. In addition to the usual controls, time effects are controlled for by adding a time dummy that captures the effect of unexpected variation or special events on the outcome variables. $\beta_{1}$ and $\beta_{2}$ are vectors of parameters to be estimated. They are assumed to be bivariate normally distributed with variances $\sigma_{\alpha_{1}}^{2}$ and $\sigma_{\alpha_{2}}^{2}$. ${ }^{6}$ The $\epsilon_{1 i}$ and $\epsilon_{2 i}$ are error terms or "idiosyncratic shocks" with a standard bivariate normal distribution with $E\left[\epsilon_{1}, \epsilon_{2}\right]=\tau$.

A full information maximum likelihood (FIML) estimate of a bivariate probit model is used to estimate the parameters of interest. The $\log$ likelihood, $\ln L$, is given as follows:

$$
\ln L=\sum_{j=1}^{n} \omega_{j} \ln \Phi_{2}\left(q_{1} \zeta_{j}^{\beta}, q_{2} \zeta_{j}^{\alpha}, \rho_{j}^{*}\right)
$$

with

$$
\begin{aligned}
& \zeta_{j}^{\beta}=x_{j} \beta+\text { offset }_{j}^{\beta} \\
& \zeta_{j}^{\alpha}=z_{j} \alpha+\text { offset }_{j}^{\alpha} \\
& S_{1 j}=\left\{\begin{array}{cc}
1, & \text { if } S_{1 j \neq 0} \neq 0 \\
-1, & \text { otherwise }
\end{array}\right. \\
& S_{2 j}=\left\{\begin{array}{cc}
1, & \text { if } S_{2 j \neq 0} \neq 0 \\
-1, & \text { otherwise }
\end{array}\right. \\
& \rho_{j}^{*}=S_{1 j} S_{2 j} \rho
\end{aligned}
$$

$\Phi($.$) is the cumulative bivariate normal distribution function with a mean vector of 0$ and $\omega_{j}$ is optional weight for observation $j$. This derivation assumes that

$$
\begin{aligned}
& S_{1 j}^{*}=x_{j} \beta+\epsilon_{1 j}+\text { offset }_{j}^{\beta} \\
& S_{2 j}^{*}=z_{j} \alpha+\epsilon_{2 j}+\text { offset }_{j}^{\alpha} \\
& E\left(\epsilon_{1}\right)=E\left(\epsilon_{2}\right)=0 \\
& \operatorname{Var}\left(\epsilon_{1}\right)=\operatorname{Var}\left(\epsilon_{2}\right)=1 \\
& \operatorname{Cov}\left(\epsilon_{1}, \epsilon_{2}\right)=\rho
\end{aligned}
$$

where $S_{1 j}^{*}$ and $S_{2 j}^{*}$ are the unobserved latent variables, we instead observe only $S_{i j}=1$ if $S_{i j}^{*}>0$ and $S_{i j}=0$ otherwise (for $i=1,2$ ).

\footnotetext{
${ }^{6}$ The covariance matrix could be written as $\left[\begin{array}{cc}\sigma_{\alpha_{1}}^{2} & \sigma_{\alpha_{1}} \sigma_{\alpha_{2}} \rho \\ \sigma_{\alpha_{1}} \sigma_{\alpha_{2}} \rho & \sigma_{\alpha_{2}}^{2}\end{array}\right]$
} 
The bivariate probit model can explain the interrelationship between storage for consumption and storage for markets from the conditional tetrachoric correlation (residual correlation) of the error terms of the two equations. A positive correlation would mean that the household's storage decision for consumption and markets are made simultaneously and they are complementary decisions. A negative correlation might indicate the mutual exclusiveness of the decisions.

\section{Results}

Data, variables, and descriptive statistics

Data description

The data for the paper comes from nationally representative household surveys of Ethiopia that collect detail information on socioeconomic characteristics of the households and agricultural production including postharvest activities ${ }^{7}$. The data is sourced from the Ethiopian Socioeconomic Survey (ESS) undertaken by the Living Standards Measurement Study and Integrated Agricultural Surveys of the World Bank which spans two rounds of the panel (2011/2012 and 2013/2014). The surveys were administered in three rounds of visits in each survey year. The first visit was carried out in September and October and collects information on agricultural activities specifically preplanting activities. This is followed by a second-round visit in November and December to administer a livestock questionnaire. The third round is conducted in January-March to collect information on postharvest agricultural activities and household characteristics. The survey generates detail information on household characteristics, crop-level information including production and disposition patterns. Georeferencing of the households enables the inclusion of climatic or agro-ecological and geographical characteristics (distance to major road, nearest markets, administration centers, or population centers). This enables studying the effect of exogenous factors such as environmental (climatic) and market forces on households' grain management decisions. While the LSMS-ISA surveys collect information on all crops produced by the sample farmers, this paper focuses on maize producing rural households. Maize is economically important grain that plays a crucial role as a food security and market crop in East and Southern Africa (Shiferaw et al. 2011). The final data is unbalanced and consist of 2934 households $^{8}$.

\section{Descriptive statistics}

Two sets of outcome measures are used in this paper. The first set of outcomes measure the level of maize grain stored and includes the total amount of maize stored during the survey time and the per capita maize stored. They are measured as continuous variables and used as dependent variables in the fixed-effects model. The second sets of outcomes used are maize stored for consumption and for markets. Both are measured as dummy variables taking a value of 1 if the household stores maize for consumption or markets. The dependent variables are computed from the postharvest module of the agriculture survey of the LSMS-ISA for Ethiopia. The survey asked the households if

\footnotetext{
${ }^{7}$ Details of the study including survey instruments, documentation, and the data can be obtained from the following website: www.worldbank.org/lsms-isa

${ }^{8}$ This is made up of 1393 households from the 2011/2012 and 1541 households from the 2013/2014 survey years.
} 
they store their maize at harvest and if they do so, what is the main purpose for their storage.

The main explanatory variables for the econometric analysis are selected based on economic theory and empirical research (Basu and Wong 2015; Kadjo et al. 2013; Oluwatoba et al. 2016). Among the data gathered on household demographics are the age, gender, and education of the household head, and the size of the household. The characteristics of the household head considered in the analysis serve as a proxy for experience, human capital, and labor availability that can affect grain storage behaviors. Wealth and liquidity indicators (size of cultivated land, livestock holding, access to credit, and non-farm income) and technological factors (improved seeds, improved storage technologies, and crop protection) also affect grain storage behavior through affecting production and risk attitude. Improved storage technologies and postharvest handling could encourage riskaverse farmers to store their produce longer for food security and get better prices for it over the season before the next harvest (Gitonga, De Groote, Kassie, and Tefera 2013).

The climatic environment and exposure to shock are key factors of risk coping behavior. The survey collects information on historical rainfall, average annual rainfall, and temperature patterns as well as those during the wettest quarter. The total amount of rainfall and the amount during the wettest quarter are used to control for the effect of pre and postharvest rainfall patterns of the survey years on households' grain storage behavior. Rainfall patterns serve as a proxy for quantities of maize harvested while conditions during the postharvest season would affect storage (Kaminski and Christiaensen 2014). The historical average rainfall is used to control for their effects on households' decisions through affecting the unobservable behaviors such as risk attitudes or attitudes toward risk. Self-reported shocks are also included. One is production shock (whether the household reports drought, poor rainfall, hailstorms, floods, or frost). Other types of shocks included are health shocks (if the household reported any illness or accident of household head, member, main bread earner, etc.) and market shocks (if the household reported unusual price fall/rise of food items and price rise of agricultural inputs).

To capture the economic incentives from the broader economic environment facing households when making their storage decisions, distance to the main market, roads, and main population centers are used. They are used as a proxy for the geographic and economic environment that would affect grain storage behavior through fostering or hindering access to markets, information, and technologies (Kaminski and Christiaensen 2014). Table 1 summarizes the basic household characteristics, wealth and liquidity indicators, labor availability, agricultural inputs, climatic and economic environment, shocks, and shock coping strategies.

\section{Maize production and disposition pattern}

Table 2 summarizes maize disposition pattern of the sample households during the two survey periods. As can be seen from the same table, the proportion of households who sold maize to the market has slightly increased from 14\% in 2012 to $17 \%$ in 2014 . However, maize grain sales remain less than $10 \%$ of the production in both periods (Fig. 1). These data suggest that own storage for consumption is an important instrument for risk coping with consumption shortfalls. 
Table 1 Description and summary of the variables used in the econometric models

\begin{tabular}{|c|c|c|c|}
\hline \multirow[t]{2}{*}{ Variables } & \multirow[t]{2}{*}{ Description } & \multicolumn{2}{|c|}{ Mean (std. dev) } \\
\hline & & 2011-2012 & 2013-2014 \\
\hline \multicolumn{4}{|l|}{ Household characteristics } \\
\hline Male headed & $=1$ if head is male; 0 if female & 0.83 & 0.81 \\
\hline Formal school & $=1$ if the head attends school; 0 otherwise & 0.31 & 0.32 \\
\hline Age of head & Age of the head in years & $44.81(15.09)$ & $46.18(14.59)$ \\
\hline Household size & Number of household members & $5.355(2.22)$ & $5.391(2.24)$ \\
\hline Livestock holding & Tropical livestock units (TLU) & $3.819(3.61)$ & $4.153(4.46)$ \\
\hline Farm size & Size of cultivated land (ha) & $1.598(6.92)$ & $1.742(4.12)$ \\
\hline Area under maize & Are allocated for maize (ha) & $0.313(0.97)$ & $0.375(1.90)$ \\
\hline Credit access & $=1$ if access credit; 0 otherwise & 0.243 & 0.240 \\
\hline Non-agribusiness & $=1$ if owns non-farm business; 0 otherwise & 0.215 & 0.277 \\
\hline Improved seed & $=1$ if used improved seed; 0 otherwise & 0.186 & 0.236 \\
\hline \multicolumn{4}{|c|}{ Climatic factors and economic environment } \\
\hline Distance to road & Distance to major road (km) & $17.17(19.14)$ & $16.80(18.61)$ \\
\hline Distance to market & Distance to nearest market $(\mathrm{km})$ & $65.63(47.59)$ & $66.24(51.24)$ \\
\hline Distance to zone capital & Distance to administration center (km) & $166.9(124.3)$ & $164.7(117.6)$ \\
\hline Annual temperature & Mean annual temperature $\left({ }^{\circ} \mathrm{C}\right)$ & $19.78(2.88)$ & $19.79(2.92)$ \\
\hline Temp. wet. quarter & Mean temperature of wettest quarter $\left({ }^{\circ} \mathrm{C}\right)$ & $19.36(2.94)$ & $19.37(2.98)$ \\
\hline Total rainfall & Annual total rainfall (mm) & $760.5(232.9)$ & $1621.8(225.9)$ \\
\hline Historical rainfall & Historical average rainfall (2001-2013) (mm) & $886.54(248.1)$ & $947.03(248.8)$ \\
\hline Rainfall wet. quarter & Total rainfall of wettest quarter (mm) & $425.4(140.1)$ & $758.2(87.74)$ \\
\hline \multicolumn{4}{|l|}{ Shocks } \\
\hline Production shocks & $=1$ if reports any production shock & 0.010 & 0.007 \\
\hline Price shocks & $=1$ if reports any price shock & 0.026 & 0.022 \\
\hline Health shocks & $=1$ if reports any health shock & 0.091 & 0.051 \\
\hline Sample size $(N)$ & Number of observations & 1393 & 1541 \\
\hline
\end{tabular}

Table 2 Maize production, market participation, and storage

\begin{tabular}{|c|c|c|}
\hline Variables & $2011 / 2012$ & $2013 / 2014$ \\
\hline \multicolumn{3}{|l|}{ Production } \\
\hline Quantity of harvest (kg) & $387.2(707.0)$ & $465.9(1736.2)$ \\
\hline \multicolumn{3}{|l|}{ Market participation } \\
\hline Sold (=1 if sold harvest) & 0.140 & 0.173 \\
\hline Amount sold (kg) & $22.88(161.8)$ & $35.10(189.2)$ \\
\hline \multicolumn{3}{|l|}{ Storage } \\
\hline Store maize (=1 if stored harvest) & 0.739 & 0.703 \\
\hline Stored amount (kg) & $192.6(439.6)$ & $224.5(577.0)$ \\
\hline Per capita storage (kg) & $42.706(150.98)$ & $48.58(156.83)$ \\
\hline \multicolumn{3}{|l|}{ Storage purpose (motives) } \\
\hline Consumption (=1 if stored for consumption) & 0.839 & 0.795 \\
\hline Sale to markets (=1 if stored for markets) & 0.152 & 0.141 \\
\hline
\end{tabular}




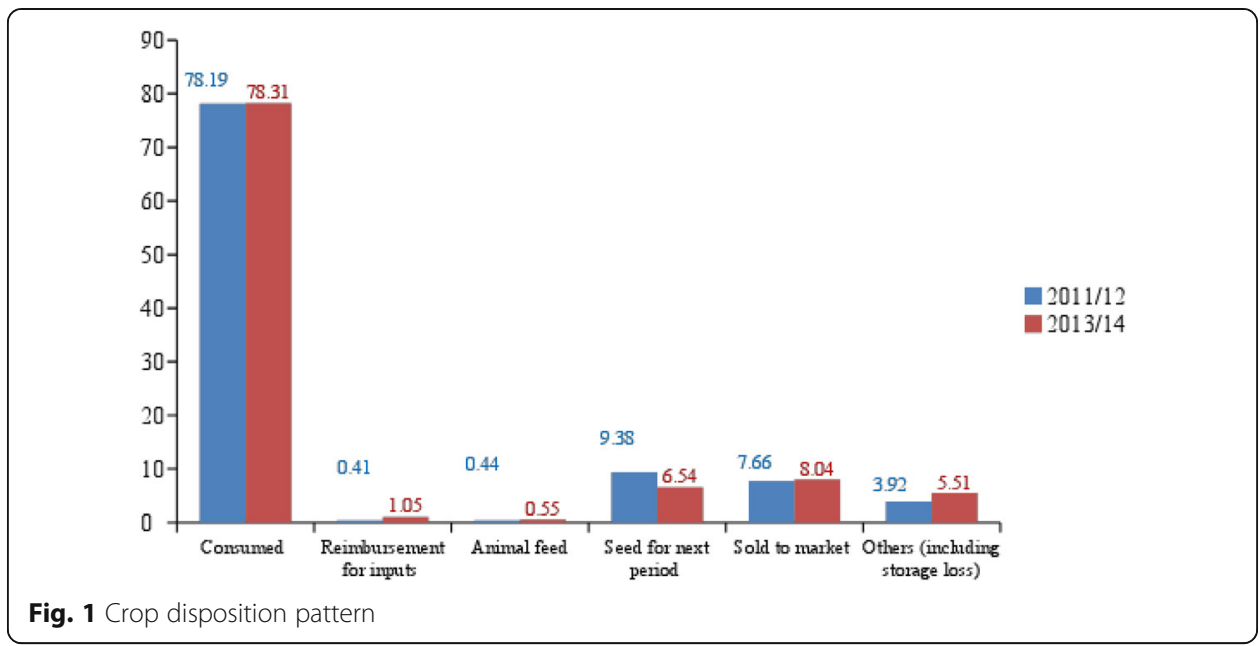

Maize grain storage is common as it is practiced by more than $70 \%$ of the sample households. Postharvest crop disposition pattern of the sample households also reveals that the inter-seasonal, or preharvest grain storage levels (amount) on average are close to half of the annual grain production. These results are significantly lower than the rates reported by Park (2006) for northwest Chinese farm households. Grain used for reimbursement of inputs such as labor, in-kind wage, and land rentals constitutes less than $2 \%$ of the production or harvest.

Analysis of the maize disposition pattern of Ethiopian maize farmers shows that more than $90 \%$ of the total maize harvest never leaves the farm (household) as it is consumed or stored for future consumption, sales, or as a seed for next planting season (Fig. 1). By so doing, farming households ensure themselves against consumption shortfalls during the lean season.

\section{Pre- and postharvest loss and storage methods}

The prevalence of postharvest storage loss has fallen from 3.9 to $0.4 \%$ (Table 3). However, the use of improved storage technologies remains discouraging in the country. Relatively, crop protection (use of chemicals) is practiced by about $22 \%$ of the sample households although it has been static. Compared to postharvest loss, the risk of preharvest loss or crop failure is prevalent. This could be associated with the limited use of crop damage prevention measures.

Table 3 Pre and postharvest maize loss and storage methods

\begin{tabular}{lll}
\hline Particulars & Year & 2013-2014 \\
\cline { 2 - 3 } & $\mathbf{2 0 1 \mathbf { 1 2 0 1 2 }}$ & 0.18 \\
\hline Improved storage use (1 = yes) & 0.18 & 21.5 \\
Crop protection (1 = yes) & 21.6 & $0.44(2.87)$ \\
Postharvest loss (\%) & $3.94(16.02)$ & 3.94 \\
Preharvest crop damage (1 = yes) & 44.8 & $14.30(22.77)$ \\
Damage proportion (\%) & $17.05(25.32)$ & 7.93 \\
Crop damage prevention (1 = yes) & 18.1 & \\
\hline
\end{tabular}


These descriptive statistics have important implications. The low adoption of improved storage technologies would mean that farmers are not considering the postharvest loss as a priority problem. It would also discourage them from storing grains for future consumption or sale to markets when prices are high. In the worst case, farmers might be financially constrained to invest in improved maize storage technologies such as the use of metallic silo.

\section{Discussion}

This section presents the econometric model results of the determinants of maize storage and the differential effects of various factors on households' maize storage for consumption (food security motives) and markets (price arbitrage motives). The econometric model results are presented in Table 4.

We start by discussing the fixed effects model estimates of the determinants of the level of maize storage at the household level. We find that the total amount of maize stored increases with the adoption of improved maize seeds and with the use of stored crop protection practices. The possible explanation for the positive association would be that improved seeds have a productivity-enhancing effect which translates into high yields and increased storage. This finding sheds new light in contrast with existing evidence that documents a tradeoff associated with the adoption of improved seeds which are high yielding but susceptible to storage loss (Ricker-Gilbert and Jones 2015). The level of maize stored (both total and per capita maize stored) increases with the use of crop protection methods. This finding corroborates the existing evidence that crop storage practices enable households to store grains by reducing the risk of storage loss (Gitonga et al. 2013; Kaminski and Christiaensen 2014; Fuglie 1995).

Shock experience is another factor found to significantly affect grain storage behavior. Preharvest loss (crop damage) significantly reduces the amount of maize stored. This is not a surprising result as the risk of crop failure has production reducing effect which could translate into low levels of consumption, sale, or storage. While the immediate channel is obvious, the risk of crop failure could also reduce the capacity of households to purchase maize from the markets. The result suggests that adoption of crop damage protection measures, particularly ex-ante risk coping instruments have the capacity to improve household welfare through improving grain savings, food security, and hence benefit from price seasonality. Likewise, we find health shocks to negatively affect maize storage. This would work in two channels. On one hand, health shocks would significantly affect labor supply for maize production which would in turn result in low production and hence low storage levels. On the other hand, health shock often results in liquidity constraints as they divert resources away to health expenditures and that would urge households to sell their crop immediately after harvest. This is consistent with the finding of Sun et al. (2013) who report a significant association between health shocks and grain selling behavior.

The only climatic factor that plays a role here is temperature. An increase in the mean annual temperature significantly reduces the amount of maize storage. This could perhaps be due to the maize yield-reducing effect of an increase in temperature. However, an increase in temperature of the wettest quarter has a positive effect on the amount of maize stored. This is possible as an increase in temperature during the 
Table 4 Determinants of maize storage and storage motives

\begin{tabular}{|c|c|c|c|c|}
\hline \multirow[t]{2}{*}{ Variables } & \multicolumn{2}{|l|}{ Grain storage $^{+}$} & \multicolumn{2}{|c|}{ Storage motives $^{++}$} \\
\hline & $\begin{array}{l}\text { Total grain stored } \\
(\mathrm{kg})\end{array}$ & $\begin{array}{l}\text { Per capita grain stored } \\
\text { (kg) }\end{array}$ & Consumption & $\begin{array}{l}\text { Price } \\
\text { arbitrage }\end{array}$ \\
\hline \multirow[t]{2}{*}{ Male headed } & -97.21 & -0.258 & -0.022 & -0.003 \\
\hline & $(89.16)$ & $(1.244)$ & $(0.079)$ & $(0.094)$ \\
\hline \multirow[t]{2}{*}{ Age of head } & 2.198 & 0.000 & 0.001 & -0.004 \\
\hline & $(2.991)$ & $(0.042)$ & $(0.002)$ & $(0.002)$ \\
\hline \multirow[t]{2}{*}{ Formal school } & 64.37 & 0.981 & -0.009 & -0.017 \\
\hline & $(44.52)$ & $(0.621)$ & $(0.068)$ & $(0.074)$ \\
\hline \multirow[t]{2}{*}{ Non-agribusiness } & -1.839 & -0.063 & $-0.167^{* *}$ & -0.097 \\
\hline & $(52.09)$ & $(0.727)$ & $(0.066)$ & $(0.072)$ \\
\hline \multirow[t]{2}{*}{ Credit access } & 19.07 & -0.585 & 0.102 & $0.125^{*}$ \\
\hline & (35.18) & $(0.491)$ & $(0.072)$ & $(0.073)$ \\
\hline \multirow[t]{2}{*}{ Household size } & 18.07 & 0.214 & 0.013 & -0.018 \\
\hline & $(12.61)$ & $(0.176)$ & $(0.014)$ & $(0.016)$ \\
\hline \multirow[t]{2}{*}{ Farm size } & 1.281 & 0.003 & 0.009 & $0.010^{* * *}$ \\
\hline & $(1.692)$ & $(0.024)$ & $(0.006)$ & $(0.003)$ \\
\hline \multirow[t]{2}{*}{ Livestock holding } & 1.070 & -0.013 & $0.022^{* * *}$ & $0.038^{* * *}$ \\
\hline & $(5.177)$ & $(0.072)$ & $(0.008)$ & $(0.009)$ \\
\hline \multirow[t]{2}{*}{ Improved storage } & -165.8 & -0.285 & $4.645^{* * *}$ & $1.104^{* *}$ \\
\hline & $(299.8)$ & $(4.182)$ & $(0.192)$ & $(0.523)$ \\
\hline \multirow[t]{2}{*}{ Crop protection } & $79.64^{* *}$ & $3.893^{* * *}$ & $0.548^{* * *}$ & $0.398^{* * *}$ \\
\hline & $(31.72)$ & $(0.442)$ & $(0.086)$ & $(0.071)$ \\
\hline \multirow[t]{2}{*}{ Preharvest loss } & $-51.90^{* *}$ & -0.373 & $-0.145^{* *}$ & $-0.165^{* *}$ \\
\hline & $(24.18)$ & $(0.337)$ & $(0.058)$ & $(0.065)$ \\
\hline \multirow[t]{2}{*}{ Improved seed } & $107.8^{* * *}$ & 0.920 & $0.297^{* * *}$ & $0.607^{* * *}$ \\
\hline & $(41.76)$ & $(0.582)$ & $(0.086)$ & $(0.075)$ \\
\hline \multirow[t]{2}{*}{ Distance to road } & 3.330 & 0.242 & $0.007^{* * *}$ & $-0.005^{* *}$ \\
\hline & $(14.74)$ & $(0.206)$ & $(0.002)$ & $(0.002)$ \\
\hline \multirow[t]{2}{*}{ Distance to market } & 8.937 & -0.194 & -0.000 & $0.004^{* * *}$ \\
\hline & $(13.88)$ & (0.194) & $(0.001)$ & $(0.001)$ \\
\hline \multirow{2}{*}{$\begin{array}{l}\text { Distance to zone } \\
\text { capital }\end{array}$} & 1.636 & -0.006 & $-0.001^{* * *}$ & $-0.001^{* * *}$ \\
\hline & $(4.800)$ & $(0.067)$ & $(0.000)$ & $(0.000)$ \\
\hline \multirow[t]{2}{*}{ Production shock } & 84.55 & 0.930 & -0.020 & $-1.230^{* *}$ \\
\hline & $(120.0)$ & $(1.674)$ & $(0.278)$ & $(0.519)$ \\
\hline \multirow[t]{2}{*}{ Price shock } & -84.47 & 1.452 & -0.010 & $0.609^{* * *}$ \\
\hline & $(73.76)$ & $(1.029)$ & $(0.201)$ & $(0.166)$ \\
\hline \multirow[t]{2}{*}{ Health shock } & $-84.86^{*}$ & $-2.012^{* * *}$ & $-0.267^{* *}$ & $-0.285^{*}$ \\
\hline & $(47.40)$ & $(0.661)$ & $(0.111)$ & $(0.149)$ \\
\hline \multirow[t]{2}{*}{ Annual temperature } & $-748.5^{* * *}$ & $-6.339^{*}$ & $0.094^{* *}$ & $-0.146^{* * *}$ \\
\hline & $(275.6)$ & $(3.844)$ & $(0.046)$ & $(0.050)$ \\
\hline \multirow[t]{2}{*}{ Temp. of wet. quarter } & $759.7^{* * *}$ & 5.677 & $-0.100^{* *}$ & $0.119^{* *}$ \\
\hline & $(266.5)$ & $(3.717)$ & $(0.046)$ & $(0.050)$ \\
\hline \multirow[t]{2}{*}{ Historical rainfall } & -0.678 & 0.017 & $0.001^{* * *}$ & $0.001^{* * *}$ \\
\hline & $(1.285)$ & $(0.018)$ & $(0.000)$ & $(0.000)$ \\
\hline
\end{tabular}


Table 4 Determinants of maize storage and storage motives (Continued)

\begin{tabular}{|c|c|c|c|c|}
\hline \multirow[t]{2}{*}{ Variables } & \multicolumn{2}{|l|}{ Grain storage $^{+}$} & \multicolumn{2}{|c|}{ Storage motives $^{++}$} \\
\hline & $\begin{array}{l}\text { Total grain stored } \\
\text { (kg) }\end{array}$ & $\begin{array}{l}\text { Per capita grain stored } \\
(\mathrm{kg})\end{array}$ & Consumption & $\begin{array}{l}\text { Price } \\
\text { arbitrage }\end{array}$ \\
\hline \multirow[t]{2}{*}{ Total rainfall } & -0.123 & $-0.004^{* *}$ & $-0.001^{* *}$ & 0.000 \\
\hline & $(0.136)$ & $(0.002)$ & $(0.000)$ & $(0.000)$ \\
\hline \multirow[t]{2}{*}{ Rainfall of wet. quarter } & 0.114 & -0.001 & $0.002^{* * *}$ & $0.002^{* * *}$ \\
\hline & $(0.190)$ & $(0.003)$ & $(0.000)$ & $(0.001)$ \\
\hline \multirow[t]{2}{*}{ Year $(1=2013 / 2014)$} & 104.7 & $2.658^{* *}$ & -0.233 & $-0.708^{* * *}$ \\
\hline & $(96.12)$ & $(1.341)$ & $(0.247)$ & $(0.271)$ \\
\hline \multirow[t]{2}{*}{ Constant } & -90.93 & 11.01 & 0.244 & $-2.276^{* * *}$ \\
\hline & (1532.3) & $(21.37)$ & $(0.313)$ & $(0.336)$ \\
\hline \multirow[t]{2}{*}{$\rho_{i j}$} & & & $0.292^{* * *}$ & \\
\hline & & & $(0.056)$ & \\
\hline $\operatorname{pr}\left(y_{1 j}=1, y_{2 j}=1\right)$ & & & 0.140 & \\
\hline $\operatorname{pr}\left(y_{1 j}=0, y_{2 j}=1\right)$ & & & 0.008 & \\
\hline $\operatorname{pr}\left(y_{1 j}=0, y_{2 j}=0\right)$ & & & 0.172 & \\
\hline $\operatorname{pr}\left(y_{1 j}=1, y_{2 j}=0\right)$ & & & 0.680 & \\
\hline $\operatorname{pr}\left(y_{1 j}=1\right)$ & & & 0.820 & \\
\hline $\operatorname{pr}\left(y_{2 j}=1\right)$ & & & 0.147 & \\
\hline$x^{2}$ & & & $1296.5^{* * *}$ & \\
\hline $\mathrm{F}$ & $1.764^{* * *}$ & $4.674^{* * *}$ & & \\
\hline $\mathrm{N}$ & 2934 & 2934 & 2934 & \\
\hline
\end{tabular}

wettest quarter makes access to maize from markets difficult, thus increasing households' incentive to store maize.

Now, we turn to the discussion of the findings from the bivariate probit model. Results of the bivariate probit estimates for the determinants of storage motives are reported in Table 4 (columns 4 and 5). Before discussing the determinants of maize storage motives, we discuss the relationship between these two maize storage motives of households. The lower panel of Table 4 shows that the correlation between the error terms in the maize storage for consumption (food security) and storage for market (price arbitrage) equations is positive and significant $\left(\rho_{i j}=\right.$ 0.292). The positive and significant correlation between the error terms in the two equations suggests that households' decisions to store grain for consumption and for the markets are made simultaneously or that the decisions are complementary. The joint and marginal probabilities show that about $14 \%$ of the sample households will store maize for markets conditional on storage for consumption. The joint probability that a household would store maize for market but not for consumption is only $8 \%$. In contrast, the probability that a household stores maize for consumption but not for markets is about $68 \%$. The probability that a randomly selected household does not store maize either for consumption or markets is $17 \%$. While our result suggests that the consumption smoothing motive for grain storage 
is stronger, there is still a room that households store maize for markets, thus supporting the price arbitrage motive.

Turning to the determinants of maize storage motives, we find many of the significant variables to have a homogenous effect on both motives (purposes) of maize storage. The risk of crop damage, improved seed adoption, distance from zonal capital or administration center, and rainfall pattern have a homogenous effect on maize storage for consumption and for markets. The probability of maize storage for consumption and markets increases with livestock holding, improved maize storage, use of crop protection, improved seed adoption, amount of the historical average rainfall and total rainfall amount of the wettest quarter. However, health shocks, the risk of crop damage, and distance to the zonal capital have a negative effect on maize storage for consumption or markets. The explanation for the positive effect of improved maize seeds adoption, and the use of crop protection methods follows similar lines of explanation provided for their positive effect on the level of maize stored. The positive correlation between livestock holding and maize storage for consumption and markets could be due to the role of livestock in providing draft power and manure that would increase maize production, thus storage. As maize yield is very likely to increase with rainfall, the positive effect is as expected.

Consistent with the theoretical prediction of this paper, some of the significant variables have a heterogeneous effect on grain storage motives. Distance to the road is negatively associated with grain storage for markets whereas its effect on grain storage for consumption is positive. This is in line with the theoretical arguments that (semi)subsistence households produce and store grains to limit their dependence on external sources of food (Renkow 1990). Households located in remote areas also would be prone to food price shocks and hence need to insulate themselves against consumption price risks through holding grain stocks (Park 2006). The mean temperature of the wettest quarter also has a heterogeneous effect on grain storage behavior. While the probability of maize storage for consumption falls with an increase in the mean temperature of the wettest quarter, the reverse works for storage for markets. This could be due to the fact that the risk of postharvest loss increases with the mean temperature of the wettest quarter (Kaminski and Christiaensen 2014). When it comes to the risk of storage loss, grain storage for markets is riskier than storage for consumption.

The probability of maize storage for consumption also falls with owning a non-farm business and total annual rainfall. Since non-farm business ownership relaxes liquidity constraints during the lean season, households may not have an incentive to hold grains to smooth consumption between the harvest and lean season. This statement is supported by economic theory which argues that holding grains is a less productive strategy compared to other instruments for managing risk such as off-farm income. The negative effect of rainfall on maize storage can be attributed to the ability for rainfall to reduce the risk profile of households. Grain storage for markets is positively associated with access to credit and farm size. The former results suggest that access to credit relaxes credit constraints and enable households to store grain and benefit from price arbitrage than selling immediately off harvest (Basu and Wong 2015; Stephens and Barrett 2011). Price shock and distance to markets are also found to be positively related to grain storage for markets. Price shocks, in this sense, are supposed to play a positive role in encouraging households to store grain and benefit from price 
seasonality. The positive coefficient for distance to market could mean that households located far from markets are not tempted to sell early. Thus, they can store their grain to be sold later in the postharvest or lean season.

\section{Conclusion}

Grain savings are deemed to be important consumption smoothing strategies among rural households who are continually exposed to yield and income shocks. This is particularly true in areas where seasonality in production is omnipresent. Thus, grain storage could be an instrument for the seasonal transfer of assets across the harvest and lean seasons in time of missing or poorly functioning credit and insurance markets. While there is a long-held belief that many farming households in developing countries prefer to grow crops which they consume than to rely on markets, one can also observe farming households produce crops for both consumption and market. Using a nationally representative panel data from maize growing rural Ethiopian households, this article sheds light on maize storage behavior and investigates the effect of climatic factors, improved storage practices, and household characteristics on grain storage behavior.

We employ fixed effects and bivariate probit models to explore the determinants of maize storage and storage motives. We find evidence that the amount of maize stored is mainly affected by technological innovations, climatic factors, and shocks. This suggests that grain storage behavior is a function of productivity-influencing factors and exposure to shocks. However, household characteristics, wealth, and the economic environment play an insignificant role in determining the level of maize stored by the household at harvest. Interestingly, our study demonstrates that households' grain storage for consumption and for markets are not mutually exclusive, they are rather complementary decisions. While households' decisions to store maize for consumption and for markets are mainly determined by the same set of factors, distance to road and climatic factors have a heterogeneous effect on the two storage motives. The results suggest that improving household welfare in the face of climatic shocks demands strategies that would increase grain production and storage. The actions may include improving households' access to productivity-enhancing and storage loss reducing technologies, integrating markets, and designing preharvest loss mitigating strategies.

\section{Acknowledgements}

We use data from the Living Standards Measurement Study-Integrated Surveys on Agriculture (LSMS-ISA) of the World Bank to produce this article. We are grateful to the editor and two anonymous reviewers who provide incisive comments that helped greatly improve the paper. We are grateful for the comments and editorial help from David Boansi and Mati Amano on the earlier draft of the paper. The views expressed here are those of the authors and should not be necessarily regarded as the official position of the institutions that we are affiliated with. The remaining errors are solely ours.

Authors' contributions

The research design was conceived by WT and GG. Data cleaning and analysis have been carried out by WT. The write up of the paper has been carried out by WT and GG. All the authors read and approved the final manuscript.

Funding

Not applicable

Availability of data and materials

The data that we used is publicly available at the World Bank website. 


\section{Author details}

${ }^{1}$ World Bank Group, 5155 Addis Ababa, Ethiopia. ${ }^{2}$ Mekelle University, 231 Mekelle, Ethiopia. ${ }^{3}$ Center for Development Research (ZEF), University of Bonn, Genscherallee 3, 53113 Bonn, Germany.

Received: 27 June 2019 Accepted: 9 September 2020

Published online: 15 October 2020

\section{References}

Ali, D. A. (2015).Household responses to shocks in rural Ethiopia livestock as a buffer stock (No. 7244).

Ashraf N, Karlan D, Yin W (2006) Tying Odysseus to the mast: evidence from a commitment savings product in the Philippines. Q J Econ 121(2):635-672

Baez, J. E., Lucchetti, L., Genoni, M. E., \& Salazar, M. (2015).Gone with the storm: rainfall shocks and household well-being in Guatemala (No. 8792).IZA Discussion Paper. Bonn, Germany.

Barrett CB, Dorosh PA (1996) Farmers' welfare and changing food prices: nonparametric evidence from rice in Madagascar. Am J Agric Econ 78:656-669

Basu K, Wong M (2015) Evaluating seasonal food storage and credit programs in east Indonesia. J Dev Econ 115:200-216 https://doi.org/10.1016/j.jdeveco.2015.02.001

Beegle K, Dehejia RH, Gatti R (2006) Child labor and agricultural shocks.Journal of. Dev Econ 81(1):80-96 https://doi.org/10. 1016/j.jdeveco.2005.05.003

Bellemare M, Barrett C, Just D (2013) The Welfare Impacts of Commodity Price Volatility: Evidence from Rural Ethiopia. Am J Agric Econ 95(4):877-899

Bezu S, Kassie GT, Shiferaw B, Ricker-Gilbert J (2014) Impact of improved maize adoption on welfare of farm households in Malawi: a panel data analysis. World Dev 59:120-131 https://doi.org/10.1016/j.worlddev.2014.01.023

Carter MR, Lybbert TJ (2012) Consumption versus asset smoothing: testing the implications of poverty trap theory in Burkina Faso. J Dev Econ 99(2):255-264 https://doi.org/10.1016/j.jdeveco.2012.02.003

Carter MR, Little PD, Mogues T, Negatu W (2007) Poverty traps and natural disasters in Ethiopia and Honduras. World Dev 35(5):835-856 https://doi.org/10.1016/j.worlddev.2006.09.010

De Janvry A, Fafchamps M, Sadoulet E (1991) Peasant Household Behaviour with Missing Markets: Some paradoxes explained. Econ J 101:1400-1417

Dercon S (2002) Income risk, coping strategies, and safety nets.The. World Bank Res Obs 17(2):141-166 https://doi.org/10. $1093 / \mathrm{wbro} / 17.2 .141$

Dercon S (2004) Growth and shocks: evidence from rural Ethiopia. J Dev Econ 74(2):309-329 https://doi.org/10.1016/j.jdeveco. 2004.01.001

Dercon S, Christiaensen L (2011) Consumption risk, technology adoption and poverty traps: evidence from Ethiopia. J Dev Econ 96(2):159-173 https://doi.org/10.1016/j.jdeveco.2010.08.003

Fafchamps M, Gubert F (2007) The formation of risk sharing networks.Journal of. Dev Econ 83(2):326-350 https://doi.org/10. 1016/j.jdeveco.2006.05.005

Fafchamps M, Lund S (2003) Risk-sharing networks in rural Philippines. J Dev Econ 71(2):261-287 https://doi.org/10.1016/ S0304-3878(03)00029-4

Fuglie KO (1995) Measuring welfare benefits from improvements in storage technology with an application to Tunisian potatoes. Am J Agric Econ 77(1):162-173 https://doi.org/10.2307/1243898

Fafchamps M, Udry C, Czukas K (1998) Drought and saving in West Africa: are livestock a buffer stock?, J Dev Econ 55(2):273305.

Gitonga ZM, De Groote H, Kassie M, Tefera T (2013) Impact of metal silos on households' maize storage, storage losses and food security: an application of a propensity score matching. Food Policy 43:44-55 https://doi.org/10.1016/j.foodpol.2013. 08.005

H. Gabriel, A., \& Hundie, B. (2006). Farmers' post-harvest grain management choices under liquidity constraints and impending risks: implications for achieving food security objectives in Ethiopia. In International Association of Agricultural Economists, Gold Goast, Australia, Ausgust 12-18, 2006 (pp. 1-17).

Hoddinott J (2006) Shocks and their consequences across and within households in rural Zimbabwe. J Dev Stud 42(2):301321 https://doi.org/10.1080/00220380500405501

Jalan J, Ravallion M (2001) Behavioral responses to risk in rural China. J Dev Econ 66(1):23-49 https://doi.org/10.1016/S03043878(01)00154-7

Janzen, S. A., \& Carter, M. R. (2013). After the drought: the impact of microinsurance on consumption smoothing and asset protection (No. 19702). Statewide agricultural land use baseline 2015. Cambridge. Retrieved from http://www.nber.org/ papers/w19702

Kadjo, D., Ricker-Gilbert, J., Alexande, C., \&Tahirou, A. (2013). Effects of storage losses and grain management practices on storage: evidence from maize production in Benin. In Agricultural \& Applied Economics Association's 2013 AAEA \& CAES Joint Annual Meeting (pp. 1-37). Washington, D.C. https://doi.org/10.1017/CBO9781107415324.004

Kaminski, J., \&Christiaensen, L. (2014). Post-harvest loss in sub-Saharan Africa-what do farmers say?Global Food Security, 3(34), 149-158. https://doi.org/10.1016/j.gfs.2014.10.002

Kazianga H, Udry C (2006) Consumption smoothing? Livestock, insurance and drought in rural Burkina Faso. J Dev Econ 79(2):413-446 https://doi.org/10.1016/j.jdeveco.2006.01.011

Kurosaki T, Fafchamps M (2002) Insurance market efficiency and crop choices in Pakistan. J Dev Econ 67(2):419-453

Lim Y, Townsend RM (1998) General equilibrium models of financial systems: theory and measurement in village economies, Rev Econ Dyn 1(1):59-118 https://doi.org/10.1006/REDY.1997.0003

McCaffre, D. F., Lockwood, J. R., Mihaly, K., \& Sass, T. R. (2012). A review of Stata commands for fixed-effects estimation in normal linear models. The Stata Journal, 12(3), 406-432. http://doi.org/The Stata Journal

Ng'ang'a SK, Bulte EH, Giller KE, Ndiwa NN, Kifugo SC, Mcintire JM et al (2016) Livestock wealth and social capital as insurance against climate risk: a case study of Samburu County in Kenya. Agric Syst 146:44-54 https://doi.org/10.1016/j.agsy.2016. 04.004 
Nguyen VC (2012) Program impact evaluation using a matching method with panel data. Stat Med 31(6):577-588 https://doi. org/10.1002/sim.4438

Oluwatoba J. Omotilewa, Ricker-Gilbert, J., Shively, G., \& Ainembabazi, H. (2016). The effects of risk perceptions and liquidity constraints on the storage decisions of maize and legume producers in Uganda.Selected Paper Prepared for Presentation for the 2016 Agricultural \& Applied Economics Association, Boston, MA, July 31-August 2.

Park A (2006) Risk and household grain management in developing countries. Econ J 116(514):1088-1115 https://doi.org/10. $1111 / j .1468-0297.2006 .01124 . x$

Paxson BCH (1992) Using weather variability to estimate the response of savings to transitory income in Thailand. Am Econ Rev 82(1):15-33

Plum, A. (2016). Bireprob: an estimator for bivariate random-effects probit models. Stata J, 16(1), 96-111. http://doi.org/The Stata Journal

Renkow M (1990) Household inventories and marketed surplus in semi-subsistence agriculture. Am J Agric Econ 72(3):664675 https://doi.org/10.2307/1243036

Ricker-Gilbert, J., \& Jones, M. (2015). Does storage technology affect adoption of improved maize varieties in Africa? Insights from Malawi's input subsidy program. Food Policy, 50(JANUARY), 92-105. https://doi.org/10.1016/j.foodpol.2014.10.015

Rosenzweig MR, Wolpin KI (1993) Credit market constraints, consumption smoothing, and the accumulation of durable credit market constraints, consumption smoothing, and the accumulation of durable production assets in low-income countries: investments in bullocks in India. J Polit Econ 101(2):223-244 https://doi.org/10.1086/261874

Saha A (1994) A two-season agricultural household model of output and price uncertainty. J Dev Econ 45(2):245-269 https:// doi.org/10.1016/0304-3878(94)90032-9

Saha, A., \& Stroud, J. (1994).A household model of on-farm storage under price risk.American Journal of Agricultural Economics, 76(3), 522-534. Retrieved from http://www.jstor.org/stable/1243663

Shiferaw B, Prasanna BM, Hellin J, Bänziger M (2011) Crops that feed the world 6. Past successes and future challenges to the role played by maize in global food security. Food Security 3(3):307-327 https://doi.org/10.1007/s12571-011-0140-5

Singh I, Squire L, Strauss J (1986) A survey of agricultural household models: recent findings and policy implications Inderjit. World Bank Econ Rev 1(1):149-179

Skoufias E (2003) Economic crises and natural disasters: coping strategies and policy implications. World Dev 31(7):1087-1102 https://doi.org/10.1016/S0305-750X(03)00069-X

Smale M, Moursi M, Birol E (2015) How does adopting hybrid maize affect dietary diversity on family farms? Micro-evidence from Zambia. Food Policy 52:44-53 https://doi.org/10.1016/j.foodpol.2015.03.001

Stephens EC, Barrett CB (2011) Incomplete credit markets and commodity marketing behaviour. J Agric Econ 62(1):1-24 https://doi.org/10.1111/j.1477-9552.2010.00274.x

Sun D, Qiu H, Bai J, Liu H, Lin G, Rozelle S (2013) Liquidity constraints and postharvest selling behavior: evidence from China's maize farmers. Dev Econ 51(3):260-277 https://doi.org/10.1111/deve.12018

Tadesse G, Guttormsen AG (2011) The behavior of commodity prices in Ethiopia. Agric Econ 42(1):87-97 https://doi.org/10, $1111 / j .1574-0862.2010 .00481 . x$

Taylor JE, Adelman I (2003) Agricultural household models: genesis, evolution, and extensions. Rev Econ Househ 1(1):33-58 https://doi.org/10.1023/A:1021847430758

Udry C (1990) Credit markets in Northern Nigeria: credit as insurance in a rural economy. World Bank Econ Rev 4(3):251-269

Udry C (1994) Risk and insurance in a rural credit market: an empirical investigation in Northern Nigeria. Rev Econ Stud 61 (3): 495-526 https://doi.org/10.2307/2297901

Udry C (1995) Risk and saving in Northern Nigeria. Am Econ Rev 85(5):1287-1300 Retrieved from http://www.jstor.org/ stable/2950989

Wright B (2001) Chapter 14 Storage and price stabilization. Handbook of Agricultural Economics, vol 1 (Part B), pp 817-861

Wright B, Williams J (1982) The economic role of commodity exchange. Econ J 92:596-192

\section{Publisher's Note}

Springer Nature remains neutral with regard to jurisdictional claims in published maps and institutional affiliations.

\section{Submit your manuscript to a SpringerOpen ${ }^{\circ}$ journal and benefit from:}

- Convenient online submission

Rigorous peer review

- Open access: articles freely available online

- High visibility within the field

- Retaining the copyright to your article

Submit your next manuscript at $\boldsymbol{\nabla}$ springeropen.com 